\title{
ALGUNAS OBSERVACIONES ACERCA DE LAS RELACIONES TEMPORALES*
}

TERESA DE JESÚS ZAVALÍA Universidad de la Plata

Los argurnentos acerca de si es posible reducir la noción de tiempo a la relación de sucesión han encontrado oposición por parte de quienes, como Mc Taggart, ${ }^{1}$ encuentran que es necesaria la tripartición de la corriente temporal en pasado, presente y futuro, y que tal repartición no es reducible a la serialización que la relación de sucesión configura.

Nosotros vamos un poco más allá y nos proponemos mostrar que ambas series, 1) anterior-posterior; 2) pasadopresente-futuro, requieren una estructura relacional más compleja para tener sentido.

La dificultad mayor consiste, a nuestro juicio, en que ni una ni otra caracterización provee una definición de ins$\operatorname{tante}^{2}$ que sea aceptable: Si se pretende brindar a esta noción el espesor dimensional que le corresponde, se incurre en paradojas tales como que un instante $p$ pertenece y no pertenece al conjunto $T$, lo que lleva a la subdivisión del instante $p$ al infinito, donde nunca es posible dar al instante $p$ una ubicación exhaustiva en el flujo temporal. Cuando se intenta la definición de instante como algo puntual y carente de dimensión temporal, se cae en la aporía

* Agradezco a Eduardo Rabossi sus oportunas observaciones durante la elaboración del presente trabajo.

1 J. M. E. Mc Taggart, The Nature of Existence, volumen II, Cambridge University Press, 1927, Book V, Cap. 33, en The Philosophy of Time, edited by Richard M. Gale, Anchor Books, New York, 1967, pp. 86-97.

a No es propósito del presente trabajo formular una definición de la noción de instante que cumpla con los requisitos señalados; tenemos en elaboración una formalización de las relaciones aquí mencionadas, que consideramos etapa previa a tal definición. 
de no explicar cómo es posible que una sucesión de instantes conforme una duración.

Una caracterización de las relaciones temporales que brinde una definición de instante que logre salvar estas dificultades ha de tener en cuenta, a nuestro juicio, la función que algo que no varía en el constante flujo temporal cumple respecto de los cambios. Si ese "permanente" no es de algún modo testigo del cambio, es decir, si no está provisto de una noción de identidad suficientemente laxa como para admitir que algo sea $x$ y sin embargo varíe de $t$ a $t^{\prime}$, su función sería nula. Lo que estamos implicando es que tal "permanente" debe ser un sujeto temporal (un sujeto a-temporal tendría una noción de identidad probablemente más rígida).

En efecto, si bastara la permanencia de las pirámides de Egipto para advertir que los árboles sufren periódicamente la caída de las hojas, no sería necesaria la presencia de una permanencia subjetiva como la que reclamamos. Una permanencia no testimonial en el sentido de la mencionada no verifica, en efecto, ciclos temporales: La noción de instante, así como la de presente se amplía en su caso, de modo que, a nuestro entender, el presente de la pirámide se extiende desde una fecha no muy fácilmente determinable de la dinastía de los Ramésidas hasta nuestro días, con el evento de la caída del revoque como única interrupción a tanta monotonía. Nos es evidente que tal permanencia no es sensible a los ciclos ni puede dar una respuesta adecuada a la noción de cambio.

¿En qué diferentes condiciones se encuentra nuestro pustulado "sujeto temporal" respecto de tales cuestiones?

Los eventos que corresponden a la lista confeccionada en base a la relación de sucesión se acumulan en él e integran un conjunto actualizable, esto es, ingresan en un pasado.

Los eventos que son incluidos como simultáneos en una

${ }^{3}$ Con las comillas queremos señalar que se trata de una descripción condensada de la constancia del sujeto temporal en su función perceptual. 
función perceptual actual configuran el presente. Aquí se podría argumentar si es posible o no incluir una mínima cuota de sucesión en ese presente; para no desviarnos de nuestra línea dejamos ahora ese problema.

Respecto de la noción de futuro, entendemos que la misma es posible sólo en función de ciclos a partir de los cuales el sujeto temporal infiere la prosecusión de los mismos. Volviendo a nuestro ejemplo de la pirámide, la noción de 'mañana' no tiene sentido para ella porque no está en relación con el evento 'noche' del mismo modo que el sujeto temporal lo está.

Adelantándonos a la posible objeción de subjetivismo con que podría interpretarse este artículo, nos importa puntualizar que no está en cuestión aquí el que los eventos de hecho ocurran, y ocurran sucesivamente, sino que tal relación no es significativa para la pirámide del ejemplo. Encontramos que sólo es significativa en el caso de un sujeto temporal. 
The arguments about the posibility of a reductio of the concept of time to that of the relation of succesion has been opposed by philosophers like Mc Taggartl according to whom it is necessary to divide the temporal flux into three parts: past, present and future; and such a distinction can not be reduced to the series based on the relation of succession.

In the present paper we go beyond that point and we attempt to show that both series: 1-earlier-later and 2-past-present-future, require to make sense, a more complex relational structure.

In our view, the main difficulty in these approaches lies in the fact that niether of them provide and adequate definition of 'instant'. If we attempt to give to this notion the dimensional thickness which corresponds to it, we are led to the statement that an instant $p$ belongs and does not belong to class $\mathrm{T}$, which implies the infinite subdivision of the instant $p$, in consequence it will never be possible to provide instant $p$ with an exhaustive placement in the temporal flux. When a definition of 'instant' as punctual and dimensionless be given, we are led to the paradox of not being able to explain how a succession of instants is a duration.

A characterization of temporal relations which provides a definition of 'instant' not liable to these difficulties will have to take into account the function fulfilled by something which does not change in the constant temporal flux with respect to the changes. If this "permanent" is not somehow witness of change, that is to say, if is not provided with a sufficiently loose concept of identity to accept that something is $x$ and nevertheles it changes from $t$ to $t$ ', it will not fulfil its function. We imply that this "permanent" should be a temporal subjet (an a-temporal subjet would probably have a more rigid concept of identity).

In fact, if the permanence of Egipt's pyramids were sufficient to realize that trees turn periodically over new leaves, would not be necessary the presence of a subjective permanence such as that we are asking for. A non-testimonial permanence, in the sense described, does not have, in fact, temporal cicles: the concept of instant as well as that of present becomes extended, in a way; we mean that the present of the pyramids extends itself from a non easily identifiable date in the dynasty of the Ramessides to our own time, where the event of a fall of a plaster is the only interruption 
of such monotony. It is evident that such permanence neither can grasp cycles nor can tell us anything about change.

What is the position of our postulate of the "temporal subject" in connexion with these questions?

The events belonging to the set of the relation of succession gather themselves and belong to a set which can be actualized, that is to say, that they enter into a past.

The present is configurated by those events which are included in an actual perception as simultaneous. It may be argued whether or not it is possible to include in this present a minimal instance of succession; since this problem will take us beyond the scope of the present work we shall not consider it here.

In connexion with the concept of future, we understand that this notion is only possible as a function of cycles from which the temporal subjects infer their continuation. Returning to our example of the pyramid, the concept of 'morning' does not make sense because it is not related to the event night in a way in which these events are related in a temporal subject. Anticipating a possible misinterpretation of the present paper we state that we are not concerned with the problem of whether those events occur and occur successively, but only with the fact that such relationship is not meaningful for the pyramid. According to us it is only meaningful in a case of a temporal subject. 